\title{
Nilai Ketakteraturan Total dari Tiga Copy Graf Bintang
}

\author{
Corry Corazon Marzuki ${ }^{1}$, Yuliana ${ }^{2}$, Yuslenita Muda $^{3}$, Mona Elviyenti ${ }^{4}$ \\ 1,2,3 Jurusan Matematika, Fakultas Sains dan Teknologi, UIN Sultan Syarif Kasim Riau \\ Jl. HR. Soebrantas No. 155 Simpang Baru, Panam, Pekanbaru, 28293 \\ Email: corry@uin-suska.ac.id, yulianazaini0@gmail.com, yuslenita.muda@uin-suska.ac.id \\ ${ }^{4}$ Prodi Teknik Elektronika Telekomunikasi Politeknik Caltex Riau \\ Jl. Umban Sari (Patin) No.1 Rumbai, Pekanbaru, 28265 \\ Email: mona@pcr.c.id
}

\begin{abstract}
ABSTRAK
Misalkan $G=(V, E)$ adalah suatu graf dan $k$ adalah suatu bilangan bulat positif. Pelabelan- $k$ total pada graf $G$ adalah suatu pemetaan yang memasangkan unsur-unsur graf yang dinotasikan dengan $\lambda: V U$ $E \rightarrow\{1,2, \ldots, k\}$. Bobot suatu titik dinyatakan sebagai penjumlahan label titik tersebut dan label sisi yang terkait dengan titik tersebut sedangkan bobot suatu sisi dinyatakan sebagai penjumlahan label sisi tersebut dan label titik yang terkait dengan sisi tersebut. Suatu pelabelan- $k$ total $\lambda: V \cup E \rightarrow\{1,2, \ldots, k\}$ dikatakan pelabelan- $k$ total tak teratur total dari graf $G$, jika bobot setiap titik berbeda dan bobot setiap sisi juga berbeda. Nilai $k$ terkecil sehingga suatu graf $G$ dapat dilabeli dengan pelabelan- $k$ total tak teratur total disebut nilai ketakteraturan total dari graf $G$, dinotasikan dengan $t s(G)$. Pada penelitian ini diperoleh nilai ketakteraturan total dari tiga copy graf bintang yang dinotasikan dengan $t s\left(3 S_{n}\right)$ yaitu $t s\left(3 S_{n}\right)=\left\lceil\frac{3 n+1}{2}\right\rceil$.
\end{abstract}

Kata Kunci: tiga copy graf bintang, nilai total ketakteraturan total, pelabelan total tak teratur total

\section{ABSTRACT}

Suppose $G(V, E)$ is a graph and $k$ is a positive integer. A total $k$-labeling on a graph $G$ is a mapping that carries of graph elements, denoted by $\lambda: V \cup E \rightarrow\{1,2, \ldots, k\}$. The weight of a vertex is represented by the sum of label of the vertex and label of every edges that incident with that vertex, where as the weight of an edge is represented by the sum of label of the edge and label of every vertices that incident with that edge. A total $k$-labeling $\lambda: V \cup E \rightarrow\{1,2, \ldots, k\}$ is called totally irregular total $k$-labeling of $\mathrm{G}$, if the weight of every vertices are different and the weight of every edges are different. The minimum $k$ such that a graph has a totally irregular total $k$-labeling is called the total irregularity strength of $G$, denoted by $t s(G)$. In this research, we determine the total irregularity strength of the three copies of star, denoted by $\operatorname{ts}\left(3 S_{n}\right)$, is $t s\left(3 S_{n}\right)=\left\lceil\frac{3 n+1}{2}\right\rceil$.

Keywords: three copies of star, total irregularity strength, totally irregular total labeling.

\section{Pendahuluan}

Teori graf terus dikembangkan, dimana dengan graf dapat merepresentasikan banyak sekali model persoalan. Dalam kehidupan sehari-hari, graf digunakan untuk menggambarkan berbagai macam struktur yang ada. Tujuannya adalah sebagai visualisasi objek-objek agar lebih mudah dimengerti [15].

Salah satu pokok bahasan dalam teori graf adalah pelabelan graf. Pelabelan graf merupakan pemasangan suatu bilangan ke setiap titik, sisi, atau keduanya. Ada beberapa jenis pelabelan graf, diantaranya pelabelan total tak teratur, pelabelan ajaib, pelabelan harmonis dan pelabelan anti ajaib [14].

Pada tahun 2007, Bača, dkk. [2] mengkaji dua jenis pelabelan- $k$ total tak teratur, yaitu pelabelan- $k$ total tak teratur titik dan pelabelan- $k$ total tak teratur sisi. Misalkan $G=(V, E)$ adalah suatu graf. Fungsi $\lambda: V \cup E \rightarrow\{1,2,3, \ldots, k\}$ disebut pelabelan- $k$ total tak teratur titik (vertex irregular total $k$-labeling) pada $G$, jika setiap dua titik yang berbeda di $V$ mempunyai bobot yang berbeda. Bobot titik $x$ di $V$ terhadap fungsi $\lambda$ adalah $w_{\lambda}(x)=$ $\lambda(x)+\sum_{x y \in E} \lambda(x y)$. Bilangan bulat positif terkecil 
$k$ sedemikian sehingga $G$ mempunyai suatu pelabelan- $k$ total tak teratur titik dinamakan nilai total ketakteraturan titik (total vertex irregularity strength) dari $G$ dan dilambangkan dengan $\operatorname{tvs}(G)$.

Pelabelan $\quad \lambda: V \cup E \rightarrow\{1,2, \ldots, k\}$ pada $G=(V, E)$ disebut pelabelan- $k$ total tak teratur sisi jika untuk setiap dua sisi yang berbeda $e$ dan $g$ pada $G$ memenuhi $w_{\lambda}(e) \neq w_{\lambda}(g)$, dimana $w_{\lambda}(e)$ dan $w_{\lambda}(g)$ berturut-turut adalah bobot dari sisi $e$ dan $g$. Bobot dari suatu sisi $e=u v$ di $G$ didefinisikan sebagai $\quad w_{\lambda}(e)=\lambda(u)+\lambda(u v)+\lambda(v) . \quad$ Nilai minimum $k$ sehingga $G$ memiliki pelabelan- $k$ total tak teratur sisi dinamakan nilai total ketakteraturan sisi dari $G$ dan dilambangkan dengan tes $(G)$.

Marzuki, dkk. [10] juga memperkenalkan suatu jenis pelabelan- $k$ total tak teratur, yaitu pelabelan- $k$ total tak teratur total. Pelabelan ini merupakan kombinasi dari pelabelan- $k$ total tak teratur titik dan pelabelan- $k$ total tak teratur sisi. Suatu pelabelan total $\lambda: V \cup E \rightarrow\{1,2, \cdots, k\}$ disebut pelabelan- $k$ total tak teratur total dari $G$ jika setiap dua titik $x$ dan $y$ yang berbeda di $V(G)$ memenuhi $w_{\lambda}(x) \neq w_{\lambda}(y)$ dan setiap dua sisi $x_{1} x_{2}$ dan $y_{1} y_{2}$ yang berbeda di $E(G)$ memenuhi $w_{\lambda}\left(x_{1} x_{2}\right) \neq$ $w_{\lambda}\left(y_{1} y_{2}\right)$ dimana $w_{\lambda}(x)=\lambda(x)+\sum \lambda(x z)$ dan $w_{\lambda}\left(x_{1} x_{2}\right)=\lambda\left(x_{1}\right)+\lambda\left(x_{1} x_{2}\right)+\lambda\left(x_{2}\right)$. Nilai $k$ minimum sedemikian sehingga $G$ memiliki pelabelan- $k$ total tak teratur total disebut nilai ketakteraturan total (the total irregularity strength) pada $G$, yang dinotasikan $t s(G)$. Pada paper yang sama, Marzuki, dkk. [10] mendapatkan nilai ketakteraturan total dari graf lingkaran dan lintasan.

Penelitian mengenai nilai ketakteraturan total ini dilakukan juga oleh peneliti lain, seperti Ramdani, dkk. [14] menentukan nilai ketakteraturan total dari beberapa hasil kali kartesian graf, Ramdani [13] juga mendapatkan nilai ketakteraturan total dari dua copy graf bintang, yaitu $t s\left(2 S_{n}\right)=n+1$. Kemudian pada tahun 2017, Julaeha, dkk. [6] memperoleh nilai ketakteraturan total dari graf bunga, yaitu $t s\left(F_{n}\right)=\left\lceil\frac{4 n+2}{3}\right\rceil$ untuk $n \geq 3$. Pada tahun yang sama, Marzuki, dkk. [9] menentukan nilai ketakteraturan total dari graf hasil kali comb $P_{m}$ dan $C_{3}$ dengan hasil ts $\left(P_{m} \triangleright C_{3}\right)=$ $\left\lceil\frac{4 m+1}{3}\right\rceil$. Pada tahun 2018, Marzuki, dkk. [10] mendapatkan nilai ketakteraturan total dari $p$-copy graf theta tak seragam, yaitu ts $(p \theta(4,4,(1,0,1,0)))=2 p+1$ untuk $p$ bilangan bulat positif.

Penelitian mengenai nilai ketakteraturan total ini terus berkembang sampai saaat ini. Pada makalah ini akan ditentukan nilai ketakteraturan total dari tiga copy graf bintang $3 S_{n}$ untuk $n \geq 2$ yang merupakan kelanjutan dari penelitian Ramdani, dkk. [13].

\section{Landasan Teori}

Teori graf pertama kali diperkenalkan pada tahun 1736 ketika Leonhard Euler mempublikasikan bukunya mengenai pemecahan masalah jembatan Konisberg yang berjudul Solution Problematis Ad Geometriam Situs Pertinentis [1]. Suatu graf didefinisikan sebagai pasangan himpunan $(V, E)$ dengan $V$ merupakan himpunan yang tidak boleh kosong dari titik-titik (vertices atau node), dan $E$ merupakan himpunan yang boleh kosong disebut sebagai sisi (edges atau arcs) [11].

Berikut ini diberikan definisi dan teorema yang dibutuhkan dalam menentukan rumus umum nilai ketakteraturan total dari tiga copy graf bintang $3 S_{n}$ untuk $n \geq 2$.

Definisi 1 [3] Suatu graf $G$ adalah suatu himpunan berhingga dan tak kosong $V$ yang dinamakan titik bersama himpunan $E$ dari subhimpunan 2-elemen dari $V$ yang dinamakan sisi. Untuk menyatakan suatu graf $G$ memiliki himpunan titik $V$ dan himpunan sisi $E$, ditulis $G=(V, E)$.

Definisi di atas menyatakan bahwa V tidak boleh kosong, sedangkan E boleh kosong.

Definisi 2 [3] Ujung dari sebuah sisi dikatakan terkait dengan sisi tersebut. Kedua titik yang terkait dengan satu sisi yang sama dikatakan bertetangga. Sedangkan dua sisi dikatakan bertetangga jika terkait dengan satu titik yang sama.

Definisi 3 [7] Derajat suatu titik pada graf adalah banyak sisi yang terkait dengan titik tersebut. Derajat titik v dinotasikan dengan $d(v)$.

Graf dapat dikelompokkan menjadi beberapa kategori atau jenis, tergantung pada sudut pandang pengelompokannya. Pengelompokan graf dapat dipandang berdasarkan ada tidaknya sisi ganda atau sisi gelang, berdasarkan jumlah titik atau berdasarkan orientasi arah pada sisi dan berdasarkan struktur [11].

Berdasarkan ada tidaknya sisi ganda atau sisi gelang pada suatu graf, maka secara umum graf dapat dibedakan menjadi dua jenis, yaitu:

1. Graf Tak Sederhana (unsimple graph)

Graf yang mengandung sisi ganda atau gelang disebut graf tak sederhana. Graf tak sederhana dibedakan atas dua jenis, yaitu graf ganda (multigraph) dan graf semu (pseudograph). Contoh dari graf tak sederhana dapat dilihat pada Gambar 1. 


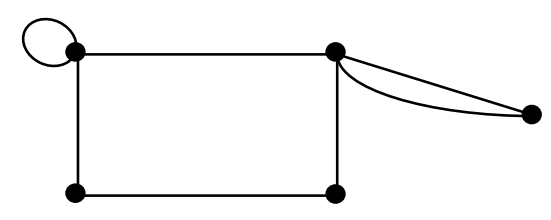

Gambar 1 Graf Tak Sederhana

2. Graf sederhana (simple graph)

Graf sederhana adalah graf yang tidak mengandung sisi ganda maupun gelang. Pada graf sederhana, sisi adalah pasangan tidak terurut (unordered pairs). Contoh dari graf sederhana dapat dilihat pada Gambar 2.

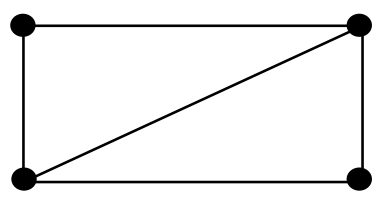

Gambar 2 Graf Sederhana

Pada graf sederhana (simple graph) terdapat beberapa graf khusus, yaitu:

a. Graf Bipartit

Suatu graf $G$ yang himpunan simpulnya dapat dipisah menjadi dua himpunan bagian $V_{1}$ dan $V_{2}$, sedemikian sehingga setiap sisi pada $G$ menghubungkan sebuah simpul di $V_{1}$ ke sebuah simpul di $V_{2}$ disebut graf bipartit dan dinyatakan sebagai $G\left(V_{1}, V_{2}\right)[2]$.

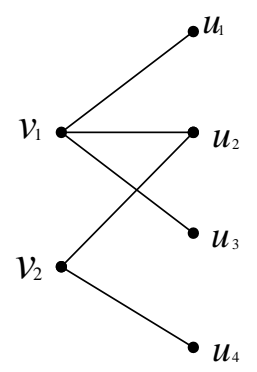

Gambar 3

b. Graf bintang

Graf bintang, dinotasikan dengan $S_{n}$ adalah suatu graf bipartit lengkap dimana himpunan bagian $V_{1}$ beranggota 1 dan $V_{2}$ beranggota sebanyak $n$. Notasi graf bipartit lengkap dengan banyaknya simpul dibagian yang satu $m$ dan bagian yang lain $n$ adalah $K_{m, n}$. Jadi $S_{n}=K_{1, n}$.

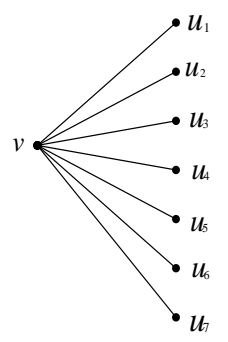

Gambar 4
Jika ada dua graf, maka dapat ditentukan apakah dua graf itu isomorfik atau tidak. Berikut syarat dua graf dikatakan isomorfik.

Definisi 4 [5] Dua graf $G_{1}$ dan $G_{2}$ dikatakan isomorfik $G_{1} \cong G_{2}$ jika terdapat pemetaan satu-satu $\varphi: V\left(G_{1}\right) \rightarrow V\left(G_{2}\right)$ sedemikiaan sehingga dua titik $v_{i}$ dan $v_{j}$ bertetangga dalam graf $G_{1}$ jika dan hanya jika titik $\varphi\left(v_{i}\right)$ dan $\varphi\left(v_{j}\right)$ juga bertetangga dalam graf $G_{2}$.

Selain itu, pada graf juga dapat dilakukan operasi. Salah satunya adalah operasi gabungan. Berikut dijelaskan mengenai operasi gabungan. Apabila graf yang digabungkan tersebut isomorfik, maka muncullah hasil copy dari graf.

Definisi 5 [4] Gabungan dari dua graf $G_{1}$ dan $G_{2}$ yang dinotasikan dengan $G_{1} \cup G_{2}$ adalah graf yang mempunyai $\quad V\left(G_{1} \cup G_{2}\right)=V\left(G_{1}\right) \cup V\left(G_{2}\right)$ dan $E\left(G_{1} \cup G_{2}\right)=E\left(G_{1}\right) \cup E\left(G_{2}\right)$. Jika $G_{1} \cong G_{2} \cong G$ maka dinotasikan dengan $2 G$ untuk $G_{1} \cup G_{2}$. Pada umumnya, jika $G_{1}, G_{2}, \ldots, G_{n}$ adalah $n$ graf yang isomorfik dengan $G$, maka $G_{1} \cup G_{2} \cup \ldots \cup G_{n}$ dinotasikan dengan $n G$ yang dinamakan $n$-copy graf G.

\section{Pelabelan Graf}

Pelabelan graf adalah pemetaan yang memasangkan elemen-elemen graf dengan bilangan-bilangan bulat positif. Suatu pelabelan dengan domain himpunan titik disebut pelabelan titik (vertex labelling), pelabelan dengan domain himpunan sisi disebut pelabelan sisi (edge labelling), dan pelabelan dengan domain gabungan himpunan titik dan himpunan sisi disebut pelabelan total (total labelling).

Salah satu jenis pelabelan adalah pelabelan total tak teratur. Pelabelan total tak teratur pertama kali diperkenalkan oleh Bača, dkk pada tahun 2007. Pelabelan total tak teratur terdiri dari pelabelan total tak teratur sisi, pelabelan total tak teratur titik dan pelabelan total tak teratur total. Berikut ini penjelasan tentang jenis pelabelan total tak teratur, yaitu :

a. Pelabelan- $k$ Total Tak Teratur Titik

Berikut definisi dari pelabelan total tak teratur titik:

Definisi 6 [2] Pelabelan- $k$ total disebut pelabelan- $k$ total tak teratur titik dari graf $G$, jika untuk setiap titik $u$ dan $v$ yang berbeda maka $w_{f}(u) \neq w_{f}(v)$, dimana

$$
w_{f}(u)=f(u)+\sum_{u x \in E} f(u x)
$$

Nilai total ketakteraturan titik (total vertex irregularity strength) dari graf $G$, yang 
dinotasikan dengan $\operatorname{tvs}(G)$ adalah label terbesar minimum yang digunakan untuk melabeli graf $G$ dengan pelabelan total tak teratur titik [2].

Hasil penelitian tentang nilai ketakteraturan titik diberikan pada teorema berikut :

Teorema 1 [2] Misalkan $G$ adalah graf $(p, q)$ dengan derajat minimum $\delta$ dan derajat maksimum $\Delta$. Maka

$$
\left\lceil\frac{p+\delta}{\Delta+1}\right\rceil \leq t v s(G) \leq p+\Delta-2 \delta+1 \text {. }
$$

b. Pelabelan- $k$ Total Tak Teratur Sisi

Berikut ini definisi pelabelan total tak teratur sisi:

Definisi 7 [2] Suatu pelabelan total $f: V \cup E \rightarrow\{1,2, \cdots, k\}$ disebut pelabelan$k$ total tak teratur sisi jika setiap dua sisi yang berbeda $u_{1} v_{1}$ dan $u_{2} v_{2}$ yang di $E(G) \quad G \quad$ memenuhi $\quad w_{f}\left(u_{1} v_{1}\right) \neq$ $w_{f}\left(u_{2} v_{2}\right)$, dengan $w_{f}\left(u_{1} v_{1}\right)=f\left(u_{1}\right)+$ $f\left(u_{1} v_{1}\right)+f\left(v_{1}\right) \quad$ dan $\quad w_{f}\left(u_{2} v_{2}\right)=$ $f\left(u_{2}\right)+f\left(u_{2} v_{2}\right)+f\left(v_{2}\right)$.

Nilai $k$ terkecil sehingga suatu graf $G$ dapat dilabeli dengan pelabelan- $k$ total tak teratur sisi, dinotasikan dengan tes $(G)$, disebut nilai total ketakteraturan sisi dari graf $G$.

Salah satu contoh pelabelan total tak teratur sisi disajikan pada Gambar 5 berikut.

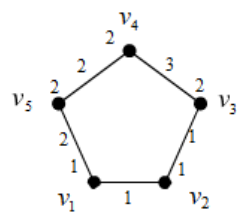

Gambar 5 Pelabelan-3 Total Tak Teratur Sisi

Hasil penelitian tentang nilai ketakteraturan sisi diberikan pada teorema berikut :

Teorema 2 [2] Misalkan $G=(V, E)$ adalah suatu graf dengan himpunan titik $V$ dan himpunan sisi tak kosong $E$, maka:

$$
\left\lceil\frac{|E|+2}{3}\right\rceil \leq \operatorname{tes}(G) \leq|E| \text {. }
$$

c. Pelabelan- $k$ Total Tak Teratur Total

Berikut ini definisi pelabelan total tak teratur total:

Definisi 8 [10] pelabelan- $k$ total tak teratur total pada $G$ adalah pemetaan $f: V \cup E \rightarrow\{1,2, \cdots, k\}$ yang memenuhi $w_{f}(u v)=f(u)+f(u v)+f(v)$ berbeda untuk setiap $u v \in E(G)$ dan $w_{f}(u)=$ $w_{f}(v)=f(v)+\sum_{u v \in E(G)} f(u v)$ berbeda untuk setiap $v \in V(G)$.

Nilai $k$ terkecil sehingga suatu graf $G$ dapat dilabeli dengan pelabelan- $k$ total tak teratur total, dinotasikan dengan $t s(G)$, disebut nilai ketakteraturan total dari graf $G$.

Marzuki, dkk. [10] juga memberikan batas bawah dari nilai ketakteraturan total dari sebarang graf $G$.

Teorema 3 [10] Untuk setiap graf $G$, berlaku $t s(G) \geq \max \{\operatorname{tes}(G), \operatorname{tvs}(G)\}$.

\section{Hasil dan Pembahasan}

Langkah awal yang dilakukan untuk mendapatkan rumus umum nilai total ketakteraturan total dari tiga copy graf bintang $\left(3 S_{n}\right)$ adalah mendefinisikaan himpunan titik dan himpunan sisi dari graf tersebut. Graf $3 S_{n}$ dapat diperoleh dengan menggandakan graf bintang sebanyak tiga kali dimana himpunan titik dan sisi dari setiap hasil penggandaan tidak ada yang beririsan. Definisikan himpunan titik dari $3 S_{n}$ adalah $V\left(3 S_{n}\right)=\left\{u_{i} \mid i=\right.$ $1,2,3\} \cup\left\{t_{j} \mid j=1,2,3, \ldots, 3 n\right\}$ dan himpunan sisi dari $3 S_{n}$ adalah $E\left(3 S_{n}\right)=\left\{u_{i} t_{j}\right.$; dengan $i=$ 1 dan $j \equiv 1(\bmod 3) ; i=2 \operatorname{dan} j \equiv$

$2(\bmod 3) ; i=3$ dan $j \equiv 0(\bmod 3)\}$.

Kemudian ditentukan batas bawah dari nilai total ketakteraturan total dari $3 S_{n}$. Setelah itu, akan dibuktikan bahwa batas bawah tersebut juga merupakan batas atas dari nilai total ketakteraturan total dari $3 S_{n}$ dengan menunjukkan adanya pelabelan total tak teratur total pada graf $3 S_{n}$ dengan menggunakan label terbesar sebesar batas bawah tersebut. Dengan demikian, terbuktilah bahwa nilai total ketakteraturan total dari $3 S_{n}$ sebesar batas bawah dan batas atas tersebut.

Dengan melakukan langkah-langkah tersebut, diperoleh suatu teorema seperti yang dinyatakan pada Teorema 4 berikut:

Teorema 4 Misalkan $3 S_{n}$ adalah tiga copy graf bintang dengan $n$ bilangan bulat positif dan $n \geq 2$ maka

$$
t s\left(3 S_{n}\right)=\left\lceil\frac{3 n+1}{2}\right\rceil
$$

Bukti :

Graf $3 S_{n}$ memiliki $3 n$ titik berderajat 1 dan 3 titik berderajat $n$. Titik berderajat 1 memiliki bobot terkecil sedikitnya 2 dan bobot terbesar sedikitnya $3 n+1$. Bobot titik berderajat 1 adalah penjumlahan dari dua label, sehingga label terbesar dari titik 
berderajat 1 sedikitnya $\left\lceil\frac{3 n+1}{2}\right\rceil$. Bobot terkecil dari suatu titik berderajat $n$ sedikitnya $3 n+2$ dan bobot terbesar dari suatu titik berderajat $n$ adalah $3 n+4$, sehingga label terbesar dari suatu titik berderajat $n$ sedikitnya $\left\lceil\frac{3 n+4}{n+1}\right]$. Dengan demikian, diperoleh $\operatorname{tvs}\left(3 S_{n}\right) \geq \max \left\{\left\lceil\frac{3 n+1}{2}\right\rceil,\left\lceil\frac{3 n+4}{n+1}\right\rceil\right\}=\left\lceil\frac{3 n+1}{2}\right\rceil$.

Selain itu, banyaknya sisi dari $3 S_{n}$ adalah $3 n$, sehingga berdasarkan Teorema 2 diperoleh $\operatorname{tes}\left(3 S_{n}\right) \geq\left\lceil\frac{3 n+2}{3}\right\rceil$.

Dengan demikian, berdasarkan Teorema 3 diperoleh batas bawah $t s\left(3 S_{n}\right)$ sebagai berikut: $t s\left(3 S_{n}\right) \geq \max \left\{\left\lceil\frac{3 n+1}{2}\right\rceil,\left\lceil\frac{3 n+2}{3}\right\rceil\right\}=\left\lceil\frac{3 n+1}{2}\right\rceil$.

Selanjutnya akan dibuktikan bahwa $t s\left(3 S_{n}\right) \geq\left\lceil\frac{3 n+1}{2}\right\rceil$. Hal ini ditunjukkan dengan cara adanya pelabelan- $\left\lceil\frac{3 n+1}{2}\right\rceil$ total tak teratur total pada graf $3 S_{n}$.

Definisikan pelabelan total $f: V\left(3 S_{n}\right) \cup E\left(3 S_{n}\right) \rightarrow$ $\left\{1,2,3, \ldots,\left\lceil\frac{3 n+1}{2}\right\rceil\right\}$ sebagai berikut:

a. Pelabelan titik (vertex) pada graf $3 S_{n}$

1. Untuk $n \in\{2,3\}$.

$$
\begin{aligned}
& f\left(u_{i}\right)=\left\{\begin{array}{l}
4 \text { untuk } i=1,2,3, \text { dan } n=2 \\
3 \text { untuk } i=1,2,3, \text { dan } n=3
\end{array}\right. \\
& f\left(t_{j}\right)=\left\lceil\frac{j}{2}\right\rceil \text { untuk } j=1,2, \ldots, 3 n
\end{aligned}
$$

2. Untuk $n \geq 4$

$$
\begin{aligned}
& f\left(f_{t j}\right)=\left\lceil\frac{j}{2}\right\rceil \text { untuk } j=1,2,3, \ldots, 3 n \\
& f\left(u_{i}\right)=1 \text { untuk } i=1,2,3,
\end{aligned}
$$

b. Pelabelan sisi (edge) pada graf $3 S_{n}$

1. Untuk $n \in\{2,3\}$

$$
f\left(u_{i} t_{j}\right)=\left\lfloor\frac{j}{2}\right\rfloor+1 \text { untuk } j=1,2, \ldots, 3 n
$$

2. Untuk $n \geq 4$

$$
\begin{aligned}
& f\left(u_{i} t_{j}\right)=\left\lfloor\frac{j}{2}\right\rfloor+1 \quad \text { untuk } \quad i=1 \text { dan } \\
& j \equiv 1(\bmod 3), i=2 \text { dan } j \equiv \\
& 2(\bmod 3), i=3 \text { dan } j \equiv 0(\bmod 3)
\end{aligned}
$$

Berdasarkan pelabelan diatas diperoleh bobot setiap titik dan bobot setiap sisi dari graf $3 S_{n}$ sebagai berikut:

1. Untuk $n=2$, bobot titik $t_{j}$ dengan $j=$ $1,2,3, \ldots, 3 n$ adalah bilangan bulat positif berurutan mulai dari 2 sampai 7. Sedangkan bobot titik $u_{i}$ dimana $i=1,2,3$ adalah 8,9,10. Jadi tidak ada bobot titik yang sama.
2. Untuk $n=3$, bobot titik $t_{j}$ dengan $j=$ $1,2,3, \ldots, 3 n$ adalah bilangan bulat positif berurutan mulai dari 2 sampai 10. Sedangkan bobot titik $u_{i}$ dimana $i=1,2,3$ adalah $11,13,14$. Jadi tidak ada bobot titik yang sama.

3. Untuk $n \geq 4$, diperoleh bobot titik dan sisi dari graf $3 S_{n}$ sebagai berikut.

a. Bobot setiap titik dari graf $3 S_{n}$

$$
\begin{aligned}
w_{f}\left(t_{j}\right) & =f\left(t_{j}\right)+f\left(u_{3} t_{j}\right) \\
& =\left\lceil\frac{j}{2}\right\rceil+\left\lceil\frac{j}{2}\right\rfloor+1 \\
& =\frac{j}{2}+\frac{j}{2}+1 \\
& =\frac{2 j}{2}+1 \\
& =j+1
\end{aligned}
$$

$w_{f}\left(u_{1}\right)=\left\{\begin{array}{l}\frac{3 n^{2}+2 n+4}{4} \text { untuk } n \text { genap } \\ \frac{3 n^{2}+2 n+3}{4} \text { untuk } n \text { ganjil }\end{array}\right.$

$w_{f}\left(u_{2}\right)=\left\{\begin{array}{l}\frac{3 n^{2}+4 n+4}{4} \text { untuk n genap } \\ \frac{3 n^{2}+4 n+5}{4} \text { untuk n ganjil }\end{array}\right.$

$w_{f}\left(u_{3}\right)=\left\{\begin{array}{l}\frac{3 n^{2}+6 n+4}{4} \text { untuk } n \text { genap } \\ \frac{3 n^{2}+6 n+3}{4} \text { untuk } n \text { ganjil }\end{array}\right.$

b. Bobot setiap sisi pada graf $3 S_{n}$

$$
\begin{aligned}
w_{f}\left(u_{i} t_{j}\right) & =f\left(u_{i}\right)+f\left(u_{i} t_{j}\right)+f\left(t_{j}\right) \\
& =1+\left\lceil\frac{j}{2}\right\rfloor+1+\left\lceil\frac{j}{2}\right\rceil \\
& =1+\frac{j}{2}+1+\frac{j}{2} \\
& =\frac{2 j}{2}+2 \\
& =j+2
\end{aligned}
$$

Jadi, untuk $n \geq 4$ diperoleh bobot titik $t_{j}$ yang dinotasikan dengan $w_{f}\left(t_{j}\right)$ dengan $j=1,2,3, \ldots, 3 n$ adalah bilangan bulat positif berurutan mulai dari $2,3, \ldots, 3 n+1$. Sedangkan bobot titik $u_{i}$ dengan $i=1,2,3$, yang dinotasikan dengan $w_{f}\left(u_{1}\right)$ adalah $\frac{3 n^{2}+2 n+4}{4}$ untuk $n$ genap dan $\frac{3 n^{2}+2 n+3}{4}$ untuk $n$ ganjil, $w_{f}\left(u_{2}\right)$ adalah $\frac{3 n^{2}+4 n+4}{4}$ untuk $n$ genap dan $\frac{3 n^{2}+4 n+5}{4}$ untuk $n$ ganjil, $w_{f}\left(u_{3}\right)$ 
adalah $\frac{3 n^{2}+6 n+4}{4}$ untut $n$ genap dan $\frac{3 n^{2}+6 n+3}{4}$ untuk $n$ ganjil. Sedangkan untuk bobot sisi $u_{i} t_{j}$ yang dinotasikan dengan $w_{f}\left(u_{i} t_{j}\right)$ dengan $i=1$ dan $j \equiv 1(\bmod 3), i=2$ dan $j \equiv$ $2(\bmod 3), i=3$ dan $j \equiv 0(\bmod 3)$ adalah $j+2$.

Berikut ini akan ditunjukan bahwa setiap bobot titik pada graf $3 S_{n}$ berbeda. Akan ditunjukkan bahwa $w_{f}\left(t_{3 n}\right)<w_{f}\left(u_{1}\right)<w_{f}\left(u_{2}\right)<w_{f}\left(u_{3}\right)$.

a. Akan ditunjukkan $3 n+1<\frac{3 n^{2}+2 n+4}{4}$ untuk setiap $n \geq 4$, menggunakan induksi matematika sebagai berikut.

1. Basis induksi

Akan ditunjukkan untuk $n=4$ berlaku

$3 n+1<\frac{3 n^{2}+2 n+4}{4}$

Perhatikan bahwa

$3 n+1=3(4)+1=13<15=\frac{3(4)^{2}+2(4)+4}{4}=\frac{3 n^{2}+2 n+4}{4}$

2. Langkah Induksi

Asumsikan benar untuk $n=k$, yaitu

$3 k+1<\frac{3 k^{2}+2 k+4}{4}$

Akan dibuktikan benar untuk $n=k+1$, yaitu:

$3(k+1)+1<\frac{3(k+1)^{2}+2(k+1)+4}{4}$

$\Leftrightarrow 3 k+4<\frac{3 k^{2}+6 k+3+2 k+2+4}{4}$

$\Leftrightarrow 3 k+4<\frac{3 k^{2}+8 k+9}{4}$

Perhatikan bahwa

$3 k+1<\frac{3 k^{2}+2 k+4}{4}$

$\Leftrightarrow 3 k+1+3<\frac{3 k^{2}+2 k+4}{4}+3$

$\Leftrightarrow 3 k+4<\frac{3 k^{2}+2 k+4+12}{4}$

$\Leftrightarrow 3 k+4<\frac{3 k^{2}+2 k+16}{4}$

$$
\begin{aligned}
& \Leftrightarrow 3 k+4<\frac{3 k^{2}+2 k+16}{4}<\frac{3 k^{2}+2 k+16}{4}+\frac{6 k-7}{4} \\
& \Leftrightarrow 3 k+4<\frac{3 k^{2}+2 k+16}{4}<\frac{3 k^{2}+8 k+9}{4} \\
& \Leftrightarrow 3 k+4<\frac{3 k^{2}+8 k+9}{4}
\end{aligned}
$$

b. Untuk $n$ genap akan ditunjukkan

$$
\begin{aligned}
& \frac{3 n^{2}+2 n+4}{4}<\frac{3 n^{2}+4 n+4}{4} \\
& \Leftrightarrow \frac{3 n^{2}+2 n}{4}<\frac{3 n^{2}+4 n}{4} \\
& \Leftrightarrow \frac{3 n^{2}+2 n}{4}+1<\frac{3 n^{2}+4 n}{4}+1 \\
& \Leftrightarrow \frac{3 n^{2}+2 n+4}{4}<\frac{3 n^{2}+4 n+4}{4}
\end{aligned}
$$

Untuk $n$ ganjil akan ditunjukkan

$$
\frac{3 n^{2}+2 n+3}{4}<\frac{3 n^{2}+4 n+5}{4}
$$$$
\Leftrightarrow \frac{3 n^{2}+2 n}{4}<\frac{3 n^{2}+4 n}{4}
$$$$
\Leftrightarrow \frac{3 n^{2}+2 n}{4}+\frac{3}{4}<\frac{3 n^{2}+4 n}{4}+\frac{3}{4}
$$$$
\Leftrightarrow \frac{3 n^{2}+2 n+3}{4}<\frac{3 n^{2}+4 n+3}{4}
$$$$
\Leftrightarrow \frac{3 n^{2}+2 n+3}{4}<\frac{3 n^{2}+4 n+3}{4}<\frac{3 n^{2}+4 n+5}{4}
$$$$
\Leftrightarrow \frac{3 n^{2}+2 n+3}{4}<\frac{3 n^{2}+4 n+5}{4}
$$

c. Untuk $n$ genap akan ditunjukkan

$$
\begin{gathered}
\frac{3 n^{2}+4 n+4}{4}<\frac{3 n^{2}+6 n+4}{4} \\
\Leftrightarrow \frac{3 n^{2}+4 n}{4}<\frac{3 n^{2}+6 n}{4} \\
\Leftrightarrow \frac{3 n^{2}+4 n}{4}+1<\frac{3 n^{2}+6 n}{4}+1 \\
\Leftrightarrow \frac{3 n^{2}+4 n+4}{4}<\frac{3 n^{2}+6 n+4}{4}
\end{gathered}
$$

Untuk $n$ ganjil akan ditunjukkan $\frac{3 n^{2}+4 n+5}{4}<\frac{3 n^{2}+6 n+3}{4}$ 


$$
\begin{aligned}
& \Leftrightarrow \frac{3 n^{2}+4 n}{4}<\frac{3 n^{2}+5 n}{4} \\
& \Leftrightarrow \frac{3 n^{2}+4 n+5}{4}<\frac{3 n^{2}+5 n+5}{4} \\
& \Leftrightarrow \frac{3 n^{2}+4 n+5}{4}<\frac{3 n^{2}+5 n+5}{4}<\frac{3 n^{2}+5 n+5}{4}+\frac{n-2}{4} \\
& \left.\left(\text { karena } \frac{n-2}{4} \geq \frac{1}{2} \geq 0\right)\right) \\
& \Leftrightarrow \frac{3 n^{2}+4 n+5}{4}<\frac{3 n^{2}+6 n+3}{4}
\end{aligned}
$$

Perhatikan bahwa fungsi $f$ adalah suatu pemetaan dari $\quad V\left(3 S_{n}\right) \cup E\left(3 S_{n}\right) \quad$ ke $\quad\left\{1,2, \ldots,\left\lceil\frac{3 n+1}{2}\right\rceil\right\}$ sedemikian sehingga setiap titik dari graf $3 S_{n}$ memiliki bobot yang berbeda dan setiap sisi dari graf $3 S_{n}$ juga memiliki bobot yang berbeda. Jadi, $f$ adalah suatu pelabelan total tak teratur total dan dapat disimpulkan bahwa $t s\left(3 S_{n}\right) \leq\left\lceil\frac{3 n+1}{2}\right\rceil$. Berdasarkan paparan diatas diperoleh bahwa $t s\left(3 S_{n}\right) \geq\left\lceil\frac{3 n+1}{2}\right\rceil \quad$ dan $\quad t s\left(3 S_{n}\right) \leq\left\lceil\frac{3 n+1}{2}\right\rceil . \quad$ Jadi terbukti bahwa $t s\left(3 S_{n}\right)=\left\lceil\frac{3 n+1}{2}\right\rceil$.

Sebagai ilustrasi dari teorema diatas, diberikan contoh pelabelan total tak teratur total untuk gi $3 S_{n}$ untuk $n=10$ dengan $t s\left(3 S_{n}\right)=\left\lceil\frac{3(10)+1}{2}\right\rceil=$ 16.

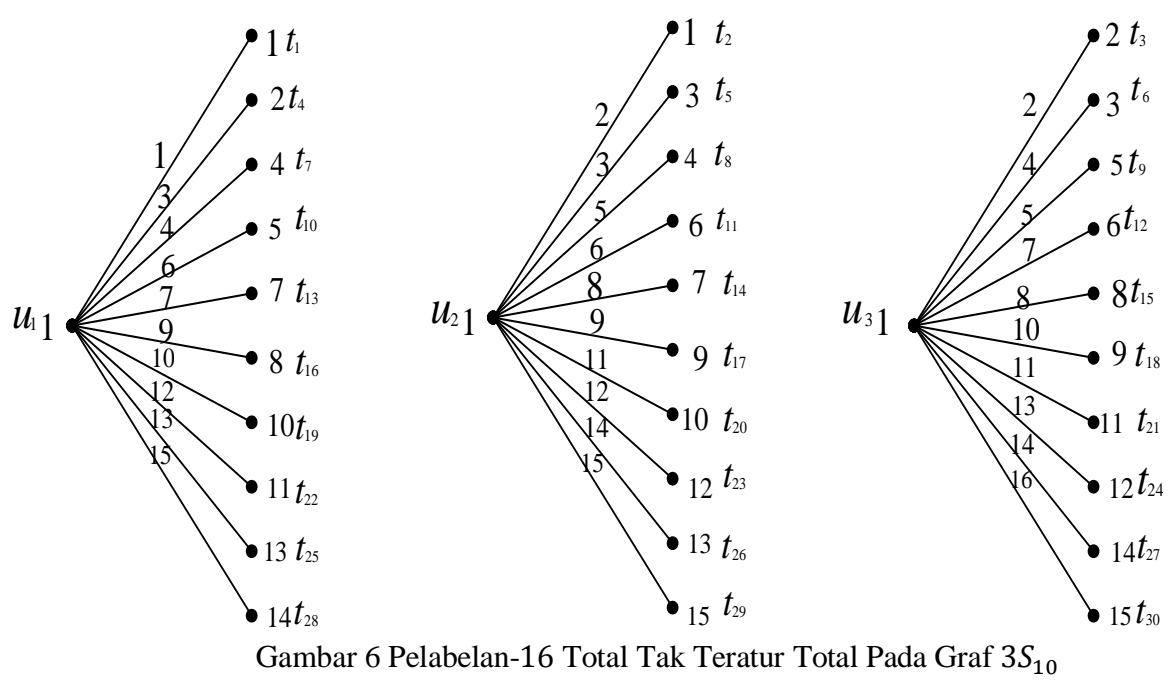

Perhatikan bahwa bobot setiap titik pada graf $3 S_{10}$ berbeda dan bobot setiap sisi pada graf $3 S_{10}$ juga berbeda. Oleh karena itu, $f$ adalah pelabelan-16 total tak teratur total pada graf $3 S_{10}$.

\section{Kesimpulan}

Berdasarkan uraian diatas tentang nilai ketakteraturan total dari tiga copy graf bintang yang dinotasikan dengan $3 S_{n}$ dapat disimpulkan bahwa $t s\left(3 S_{n}\right)=\left\lceil\frac{3 n+1}{2}\right\rceil$. Hal ini telah dibuktikan dengan $\quad t s\left(3 S_{n}\right) \geq\left\lceil\frac{3 n+1}{2}\right\rceil$ dan $t s\left(3 S_{n}\right) \leq$ $\left\lceil\frac{3 n+1}{2}\right\rceil$. Untuk $t s\left(3 S_{n}\right) \leq\left\lceil\frac{3 n+1}{2}\right\rceil$ dibuktikan dengan cara menunjukkan adanya pelabelan- $\left\lceil\frac{3 n+1}{2}\right\rceil$ total tak teratur total pada graf $3 S_{n}$. Hasil ini diharapkan dapat berkontribusi dalam mendapatkan nilai ketakteraturan total dari m-copy graf bintang yang dinotasikan dengan $m S_{n}$.

\section{Daftar Pustaka}

[1] A. Ghofur, "Pewarnaan Titik pada Graf yang Berkaitan dengan Sikel”. Skripsi, Universitas Islam Negri Malang, Malang, 2008.

[2] Baca, M., Jendrol, S., Miller, M., Ryan, J., On Irregular Total Labelings, Discrete Math., 307, 2007. 1378-1388.

[3] Chartrand, G., Lesniak L., Zhang P., Graphs and Digraphs $5^{\text {th }}$ edition, CRC Press. New York. 2011.

[4] Chartrand, Gary and O. R. Oellermann. (1993). Applied and Algorithmic graph Theory. McGraw-Hill Inc, New York.

[5] Chartrand, Gary. (1986). Introductory Graph Theory. Dover Publications Inc, New York.

[6] Julaeha, Siti, Ita Luspitasari, and Esih Sukaesih. "Pelabelan Total Tak Teratur Total 
pada Graf Bunga." JURNAL ISTEK 10.1 2017.

[7] Marzuki, C.C., Handayani, S., Aryani, F., "Nilai Ketakteraturan Total dari p-copy Graf Theta Tak Seragam." Seminar Nasional Teknologi Informasi Komunikasi dan Industri. 2018.

[8] Marzuki, C.C., Febrinanda,Y. "Nilai Ketakteraturan Total dari Graf Hasil Kali Comb $P_{m}$ dan $C_{4}$,"Jurnal Sains Matematika dan Statistika”. Vol. 3 No. 2, halaman 8-15. 2017.

[9] Marzuki, Corry Corazon, Riandari, R., "Nilai Ketakteraturan Total dari Graf Hasil Kali comb $P_{m}$ dan $C_{3}$ ". Jurnal Sains Matematika dan Statistika.Vol. 3. No. 1.2017.

[10] Marzuki, C.C., Salman A.N.M., Miller, M., "On The Total Irregularity Strength of Cycles and Paths" Far East Journal of Mathematical Sciences. Vol. 82, halaman 121, 2013.

[11] Munir, R. "Matematika Diskrit". Revisi Kelima,. Informatika Bandung, Bandung. 2012.

[12] Purwanto. "Teori Graf'. Malang: IKIP MALANG. 1998.

[13] Ramdani, R. "Nilai Total Ketakteraturan Total dari Dua Copy Graf Bintang." JURNAL ISTEK 8.2 2014.

[14] Ramdani, R., and A. N. M. Salman. "On The Total Irregularity Strength of Some Cartesian Product Graphs." AKCE International Journal of Graphs and Combinatorics 10.2 (2013): 199-209.

[15] Siang, J.J. "Matematika Diskrit dan Aplikasinya Pada Ilmu Computer". Edisi Empat, halaman 217. Andi, Yogyakarta. 2009. 